\title{
How to build consumer trust towards e-satisfaction in e-commerce sites in the covid-19 pan- demic time?
}

\author{
Ina Ratnasari ${ }^{a *}$, Salim Siregar ${ }^{a}$ and Asep Maulana ${ }^{a}$
}

\begin{tabular}{l}
${ }^{a}$ Universitas Singaperbangsa Karawang, \\
\hline C H R O N I C L E \\
\hline Article history: \\
Received: September 20, 2020 \\
Received in revised format: \\
January 15, 2021 \\
Accepted: January 16, 2021 \\
Available online: January 16, 2021 \\
\hline Keywords: \\
Consumer trust \\
e-satisfaction \\
e-service quality \\
e-security \\
Strategic marketing \\
covid-19
\end{tabular}

\section{Introduction}

Currently, the spread of covid-19 virus in Indonesia is increasingly widespread. The increasing outbreak of this virus has had a very significant impact on consumer behavior in carrying out activities such as shopping. Tran (2020) suggests that people's fears during the covid-19 pandemic have increased people's interest in shopping online. The products and services offered by e-commerce have provided economic benefits and had a positive influence on the sustainability of consumption in the era of the covid-19 pandemic. Devita (2020) summarizes the online shopping habits of Indonesians utilizing impression data from Google Analytics during the period march 2020 and February 2020. Here are some interesting highlights around the increased interest in Indonesian products during the COVID-19 pandemic. The research was conducted by tracking the interest of Online Shopping of Indonesians towards a number of products during the Covid-19 period. The instrument used to know consumer interest is impression data in Google Analytic, and the data is taken by comparing the period 1-29 February and 1-29 March 2020. The Research finds that the interest in shopping for hand sanitizer products increased significantly by $5.585 \%$ compared to before the Covid-19 pandemic, followed by interest in buying vitamin $\mathrm{C}$ increased by $1.986 \%$, hygiene soap products such as Dettol increased by $1.395 \%$, Thermometer buying interest increased by $1.007 \%$, and lastly interest in buying mouth mask

* Corresponding author.

E-mail address: ina.ratnasari@fe.unsika.ac.id (I. Ratnasari)

(C) 2021 by the authors; licensee Growing Science, Canada. doi: $10.5267 /$ j.ijdns.2021.2.001 
products increased by $1.67 \%$. This indicates that online shopping sites are currently popular and are the top choice for shopping. In addition to health products, it turns out that interest in buying non-health products is also increasing. The research finds buying interest in non-health products during the Covid-19 season on online shopping sites has also increased significantly. This is indicated by the increase in buying interest in webcam products by $1.572 \%$, interest in buying bicycle products by $1,036 \%$, interest in buying Aloe vera by $414 \%$ and paper by $377 \%$.

Indonesia is among the countries that ranked first in the ranks of those countries with $78 \%$ growth in 2018 . More than 100 million internet users in Indonesia make Indonesia one of the countries that have the power to drive the growth of e-commerce. UK-based research institute, Merchant Machine says that the average money spent by Indonesians on online shopping sites reaches US\$ 228 per person or about IDR 3.19 million per person. And 17.7\% of respondents spent their money on buying plane tickets and booking hotels online. A total of $11.9 \%$ of respondents spent their money on clothing and footwear or shoes. The third most popular category was health and beauty products selected by $10 \%$ of respondents. Indonesia is a country that can accept change quickly. This causes e-commerce in Indonesia to grow over the years and more and more businesses, both large-scale and retail companies, are moving towards digital. Indonesia has a population of 250 million, making the potential for the development of Indonesia's e-commerce very large. It is also supported by the continued growth of internet user penetration, the increasing affordability of internet connection prices, as well as the considerable enthusiasm of the public in using the internet to support daily life. According to a report from McKinsey, in Indonesia the e-commerce sector itself has generated more than 5 billion dollars from the formal business of E-tailing and also more than 3 billion dollars from informal trading.

One of the largest e-commerce in Indonesia was Tokopedia. It was able to compete and became second as an E-Commerce site that many people visited and has become one of the most popular sites in Indonesia. Currently, Tokopedia, was transformed into a unicorn, which has an influence not only in Indonesia but also in Southeast Asia. As covid-19 pandemic gives huge impact for business, this research was conducted to determine the effect of E-service quality and e-security on trust towards E-Satisfaction in the largest e-commerce site in Indonesia by conducting the research objective of Tokopedia customers.

\section{Literature Review and Hypotheses}

The biggest challenge for online shopping is to provide and maintain customer satisfaction. The quality of service in an online or electronic environment is one of the most important things in determining the success even of failures in the e-commerce business. E-satisfaction describes how the quality of the e-service quality is acceptable and benefits users of the company's website online. According to Srinivasan et al. (2002), Liu (2012), e-satisfaction is a form of customer satisfaction resulting from its shopping activities. A key success factor to survive in a fierce competitive e-environment is a strategy that focuses on services. A company must deliver superior service experiences to its customers, so that they will repurchase and be loyal to the firm (Gounaris et al., 2010). In order to obtain high levels of customer satisfaction, high service quality is needed, which often leads to favorable behavioral intentions (Brady and Robertson, 2001). A website with good system quality, information quality, and electronic service quality is a key to success in e-commerce (Sharma \& Lijuan, 2015). Rita et al. (2019) found that e-service quality has a significant effect on customer trust and customer satisfaction of online shopping sites in Indonesia. Flavian et al. (2006), Bulut (2015) define e-satisfaction as a consumer's feeling about the website resulting from the aspects that make up the consumer relationship with the company (Chauke, \& Dhurup, 2017; Bi \& Kim, 2020).

\section{$\mathrm{H}_{1}$ : E-service quality has a positive effect on e-satisfaction.}

$\mathrm{H}_{2}$ : E- service quality has a positive effect on trust.

Another factor that also affects consumer satisfaction online is the safety factor. The level of cybercrime in Indonesia is very worrying, Indonesia being the first country to get the most attacks in cyberspace. The Internet makes crimes that were originally conventional evolve into modern crimes with greater levels of loss and far-larger impacts. For example, e-commerce crimes experienced by Tokopedia lately where there is data theft by an unauthorized third party related to the company user information. Cited from cnbcindonesia.com (2020), cases of leakage of 91 million user data include control of the personal data of the company account owner without the account owner's consent. Personal data in the form of user email id, date of birth, gender and telephone number. The issue of data theft experienced by the company can illustrate how bad the security system is owned by the company, this of course greatly affects consumer perceptions about e-commerce so that it has an impact on customer satisfaction level. In mobile commerce, consumers are facing higher security and privacy risks because of the data transaction in a wireless environment (Wei et al., 2009; Chong et al., 2010). Leakage of personal data can be used by parties who are not responsible for various criminal acts. the risk of leakage of personal data can also be used to commit fraud to apply for an online loan using your personal identity. According to Nuseir et al. (2010), security can have a different meaning for everyone and in different contexts when shopping online. As a new marketing channel, E-commerce contains more uncertainty and risk than conventional purchases. This is because the seller and the buyer do not see each other at the time of the transaction. Online crime is inevitable. With the security guarantee provided, it is expected that consumer users can make transactions more securely and not be alarmed by fraud at the time of the transaction. So the security guarantee offered is suspected to have a positive influence on consumer satisfaction (e-satisfaction). Furthermore, customer satisfaction, security is also the most important factor in building trust. 
$\mathrm{H}_{3}$ : E-Security has a positive effect on e-satisfaction.

$\mathrm{H}_{4}$ : E-Security has a positive effect on trust.

Today's consumers are very critical in determining the product they will buy. According to Engel et al. (1968), Sumarwan (2011: 387), customer satisfaction is an after-purchase evaluation where the chosen alternative at least gives results (outcome) equal to or exceeds customer expectations. These expectations result from the quality of service and customer experience in shopping activities. Customer satisfaction can be affected by the e-service quality and e-security provided by the company in the product purchasing process. Abid and Purbawati (2020) showed that e-security and e-service quality has a simultaneous effect on e-satisfaction. Chang et al. (2013) stated that trust is the most important factor to attract e-commerce buyers. Oliveiera (2017) found that e-commerce and trust fields are both very rich in terms of literature, which is increasing by the day, mainly at an independent level, and in very specific factor analyses. However, studying these two fields together whilst considering all the dimensions and sources of consumer trust, has received limited interest, which represents an opportunity for improvement. This study formulates and empirically tests a path model to explain how consumers' overall trust influences their online purchase intention. According to Chang et al. (2013), lack of trust is a major barrier in the adoption of e-commerce. Oliveira et al. (2017) measured three dimensions of customer trust (competence, integrity, and benevolence) and found that customers with high overall trust demonstrated a higher intention to e-commerce. This research will try to analyze the influence of e-service quality and e-security on e-satisfaction with variable moderating customer trust. Thus trust can increase customer satisfaction shopping online. Laely (2016) found that trusts have an effect on customer satisfaction. The higher the trust, the higher the customer satisfaction to the company.

$\mathrm{H}_{5}$ : E-service quality and e-Security have simultaneous effects on e-satisfaction.

$\mathrm{H}_{6}$ : Trust has an effect on e-satisfaction.

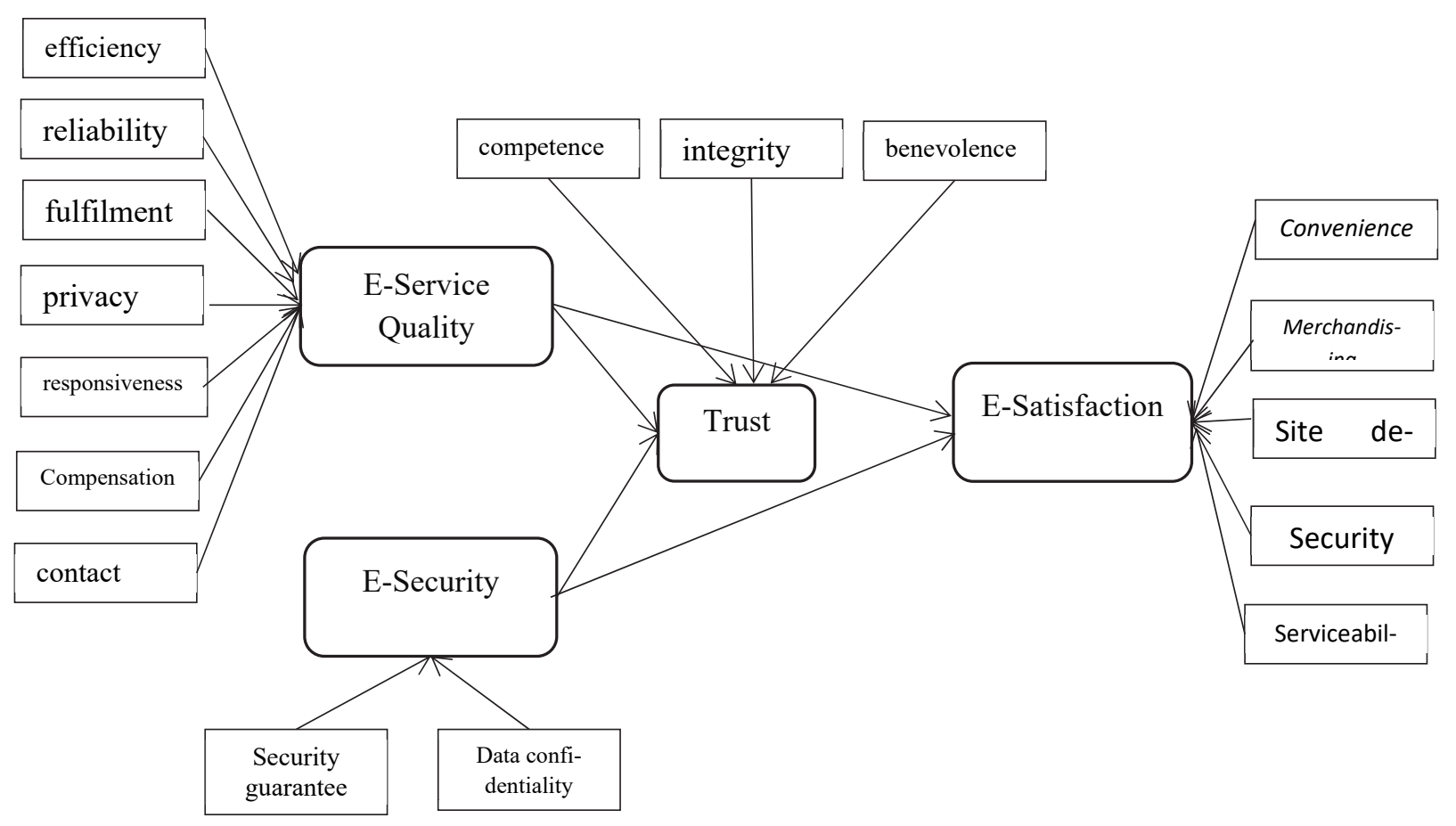

\section{Research Method}

Fig. 1. Conceptual Model

This study used a quantitative research approach, because the data sought, collected and processed in the form of numbers or statistics. Sugiyono (2017), quantitative approach is an attempt to measure the variables in the study to then look for a relationship between those variables. In using quantitative approach testing validity and reliability is an absolute condition that must be met, if not fulfilled it will affect the quality of research that is being done. The operationalization of e-satisfaction variables refers to Ranjbarian et al. (2012) namely, convenience, merchandising, site design, security, serviceability. The operationalization of trust variables refers to Oliveira et al. (2017) measured three dimensions of customer trust are competence, integrity, and benevolence. The operationalization of e-service quality variables refers to Parasuraman et al. (1985), Tjiptono and Chandra (2019) namely efficiency, reliability, fulfilment, privacy, responsiveness, compensation, contact. While the operationalization of variables of e-security refers to Raman and Annamalai (2011) namely security guarantees and data confidentiality. A full list of instruments used in this study can be found in Table 1. 
Table 1

Research Instrument

\begin{tabular}{|c|c|c|c|c|c|}
\hline Variable & Dimension & Indicator & Variable & Dimension & Indicator \\
\hline \multirow{10}{*}{$\begin{array}{l}\text { E-Service } \\
\text { Quality } \\
\text { (X1) }\end{array}$} & \multirow[t]{2}{*}{ Efficiency } & X11. Ease of accessing the website & \multirow[t]{10}{*}{ Trust (Y) } & \multirow[t]{4}{*}{ Competence } & $\begin{array}{l}\text { Y1. Able to fulfill every promise given } \\
\text { to consumers }\end{array}$ \\
\hline & & X12. Sites can load pages quickly & & & $\begin{array}{l}\text { Y2. Products and services offered in } \\
\text { accordance with what is promised }\end{array}$ \\
\hline & Reliability & X13. Error-free and accurate & & & $\begin{array}{l}\text { Y3. Consistent in selling good products } \\
\text { and high service }\end{array}$ \\
\hline & \multirow[t]{2}{*}{ Fulfillment } & X14. Honesty over any offer made & & & $\begin{array}{l}\text { Y4. Relied upon to meet the needs of } \\
\text { consumers }\end{array}$ \\
\hline & & $\begin{array}{l}\text { X15. Provide availability information } \\
\text { products clearly }\end{array}$ & & \multirow[t]{3}{*}{ Integrity } & $\begin{array}{l}\text { Y5. The items offered according to the } \\
\text { description }\end{array}$ \\
\hline & Privacy & X16. Protect customers' personal data & & & $\begin{array}{l}\text { Y6. Able to maintain to always put the } \\
\text { interests of consumers first }\end{array}$ \\
\hline & \multirow[t]{2}{*}{ Responsiveness } & X17. Speed in confirming payments & & & Y7. Respond complaints \\
\hline & & $\mathrm{X} 18$. Respond quickly to problems & & \multirow[t]{3}{*}{ Benevolence } & Y8. Does not harm consumers \\
\hline & Compensation & X19. Offer refund & & & Y9. Providing Benefits when shopping \\
\hline & Contact & $\begin{array}{l}\text { X110. Providing contact services for } \\
\text { consumers }\end{array}$ & & & \\
\hline \multirow{10}{*}{$\begin{array}{l}\text { E-Security } \\
\text { (X2) }\end{array}$} & Security & X21. Security guarantees & \multirow{10}{*}{$\begin{array}{l}\text { E- } \\
\text { satisfaction } \\
(Z)\end{array}$} & \multirow[t]{3}{*}{ Convenience } & Z1. Save time in shopping \\
\hline & \multirow[t]{5}{*}{ Guarantee } & X22. Confidentiality of personal data & & & Z2. Providing a shopping experience \\
\hline & & $\mathrm{X} 23$. Guarantee in providing information & & & Z3. Easy to find what you need \\
\hline & & $\begin{array}{l}\text { X24. Guaranteed protection against } \\
\text { denial from the seller }\end{array}$ & & Merchandising & $\begin{array}{l}\text { Z4. Various offers or promotions } \\
\text { (e.g. discounts, free shipping, etc.) }\end{array}$ \\
\hline & & $\begin{array}{l}\text { X25. Guaranteed data and secure } \\
\text { information }\end{array}$ & & \multirow[t]{3}{*}{ Site design } & $\begin{array}{l}\text { Z5. Directional guidance in finding } \\
\text { the search menu, login, and other }\end{array}$ \\
\hline & & X26. Ease of payment & & & Z6. Interesting website view \\
\hline & \multirow[t]{4}{*}{$\begin{array}{l}\text { Data } \\
\text { Confidentiality }\end{array}$} & $\begin{array}{l}\text { X27. Safe in carrying out the purchase } \\
\text { activity }\end{array}$ & & & $\begin{array}{l}\text { Z7. Always update providing } \\
\text { information }\end{array}$ \\
\hline & & X28. Data cannot be modified by hackers & & Security & $\begin{array}{l}\text { Z8. Properly protect privacy (ex: } \\
\text { shopping activities) }\end{array}$ \\
\hline & & X29. Engineering capacity & & Serviceability & Z9. Provision of complaint services \\
\hline & & $\begin{array}{l}\text { X210. Security in making payments } \\
\text { electronically }\end{array}$ & & & $\begin{array}{l}\text { Z10. Completeness of information } \\
\text { (seller history, delivery status, etc.) }\end{array}$ \\
\hline
\end{tabular}

Source: Parasuraman et al. (1985), Tjiptono \& Chandra (2019), Oliveira et al. (2017)

Raman \& Annamalai (2011), Ranjbarian et al. (2012)

The population in this study was a user of the Tokopedia app in the Tokopedia Group on Facebook, with a population of 5,558 members. The calculation of the number of samples using the Slovin formula is obtained as many as 400 samples using a $5 \%$ error rate. Data validity testing can be done in various ways, one of which is by using PLS-SEM (Partial Least Square) technique. PLS (Partial Least Square) is a variant-based structural equation analysis (SEM) that can simultaneously test measurement models as well as structural model testing. Measurement models are used for validity and reliability tests, while structural models are used for causality tests (hypothesis testing with prediction models) Sarjito (2013). Data validity tests on PLS-SEM techniques are conducted at the validity and reliability test stages or commonly referred to as outer models with the help of smartpls 3.0 Software. Outer model testing is carried out to assess the validity and reliability of the model conducted by algorithm analysis.

\section{Result and Discussion}

The measurement model testing consists of testing convergent validity (Outer Loading dan AVE), discriminant validity (Cross Loading), and composite reliability (Cronbach's Alpha dan Composite Reliability). The outer loading test is based on the criteria stated by (Ghozali, 2014) i.e., the outer loading value is $>0.7$. Table 2 shows the results of outer loading.

Table 2

Outer loading test results

\begin{tabular}{|c|c|c|c|c|c|c|c|}
\hline Indicator & $\begin{array}{l}\text { (X1) } \\
\text { E-Service Quality }\end{array}$ & Indicator & $\begin{array}{l}\text { (X2) } \\
\text { E-Security }\end{array}$ & Indicator & (Y) Trust & Indicator & $\begin{array}{l}\text { (Z) } \\
\text { E-Satisfaction }\end{array}$ \\
\hline X11 & 0.718 & $\mathrm{X} 21$ & 0.711 & Y1 & 0.772 & Z1 & 0.768 \\
\hline $\mathrm{X} 110$ & 0.613 & $\mathrm{X} 210$ & 0.816 & Y10 & 0.785 & $\mathrm{Z} 2$ & 0.860 \\
\hline X12 & 0.809 & X22 & 0.727 & Y2 & 0.768 & $\mathrm{Z3}$ & 0.790 \\
\hline $\mathrm{X} 13$ & 0.661 & $\mathrm{X} 23$ & 0.778 & Y3 & 0.796 & Z4 & 0.797 \\
\hline $\mathrm{X} 14$ & 0.738 & $\mathrm{X} 24$ & 0.714 & Y4 & 0.842 & $\mathrm{Z5}$ & 0.689 \\
\hline $\mathrm{X} 15$ & 0.695 & $\mathrm{X} 25$ & 0.892 & Y5 & 0.775 & Z6 & 0.803 \\
\hline $\mathrm{X} 16$ & 0.646 & $\mathrm{X} 26$ & 0.692 & Y6 & 0.814 & $\mathrm{Z7}$ & 0.777 \\
\hline $\mathrm{X} 17$ & 0.734 & $\mathrm{X} 27$ & 0.824 & Y7 & 0.792 & Z8 & 0.777 \\
\hline X18 & 0.714 & $\mathrm{X} 28$ & 0.854 & Y8 & 0.742 & Z9 & 0.706 \\
\hline X19 & 0.605 & $\mathrm{X} 29$ & 0.792 & Y9 & 0.782 & & \\
\hline
\end{tabular}


Based on these results, it can be seen that several indicators are at a value of $<0.7$ so that they can be dropped from the research one by one starting from the indicator with the smallest outer loading result. So, based on this, indicators that are declared invalid can be removed from the research model, resulting in a new research model and then re-testing for validity with the following results:

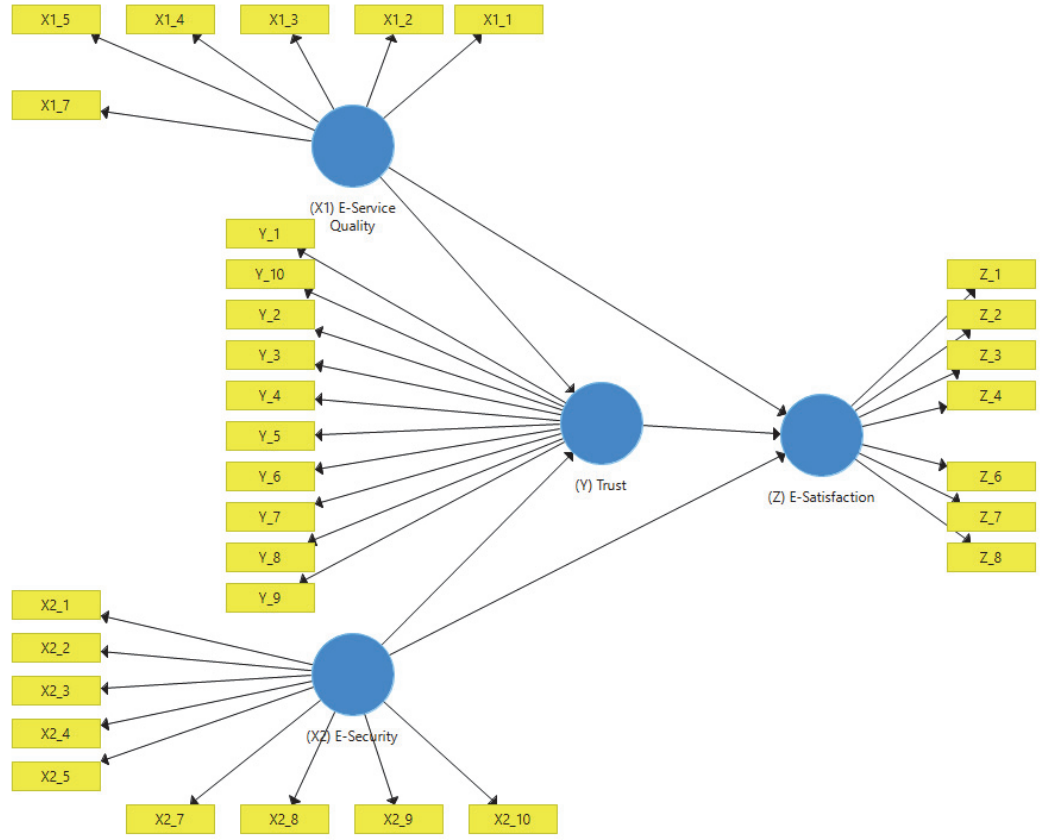

Fig. 2. PLS-SEM 2 Path Diagram

Fig. 2 is a test result of the validity of model 2 which will then be tabulated so that it is easy to understand. Table 3 shows test results for the validity of the PLS-SEM 2 path chart.

Table 3

Outer loading test results

\begin{tabular}{|c|c|c|c|c|c|c|c|}
\hline Indicator & $\begin{array}{l}\text { (X1) } \\
\text { E-Service Quality }\end{array}$ & Indicator & $\begin{array}{l}\text { (X2) } \\
\text { E-Security }\end{array}$ & Indicator & $\begin{array}{l}\text { (Y) } \\
\text { Trust }\end{array}$ & Indicator & $\begin{array}{l}\text { (Z) } \\
\text { E-Satisfaction }\end{array}$ \\
\hline $\mathrm{X} 11$ & 0.787 & $\mathrm{X} 21$ & 0.714 & Y1 & 0.772 & $\mathrm{Z1}$ & 0.780 \\
\hline $\mathrm{X} 12$ & 0.819 & $\mathrm{X} 210$ & 0.807 & Y10 & 0.784 & $\mathrm{Z} 2$ & 0.884 \\
\hline $\mathrm{X} 13$ & 0.737 & $\mathrm{X} 22$ & 0.740 & Y2 & 0.766 & $\mathrm{Z3}$ & 0.811 \\
\hline X14 & 0.745 & $\mathrm{X} 23$ & 0.792 & Y3 & 0.797 & Z4 & 0.796 \\
\hline $\mathrm{X} 15$ & 0.712 & $\mathrm{X} 24$ & 0.701 & Y4 & 0.842 & Z6 & 0.808 \\
\hline \multirow[t]{5}{*}{$\mathrm{X} 17$} & \multirow[t]{5}{*}{0.761} & $\mathrm{X} 25$ & 0.899 & Y5 & 0.776 & $\mathrm{Z7}$ & 0.773 \\
\hline & & $\mathrm{X} 27$ & 0.839 & Y6 & 0.814 & Z8 & 0.800 \\
\hline & & $\mathrm{X} 28$ & 0.847 & Y7 & 0.794 & & \\
\hline & & $\mathrm{X} 29$ & 0.803 & Y8 & 0.740 & & \\
\hline & & & & Y9 & 0.782 & & \\
\hline
\end{tabular}

Based on the results of the outer loading test in the second model, all indicators are declared valid because they are $>0.7$. After all statements are declared valid, then the PLS Algorithm - AVE (Average Variance Extracted) AVE test is carried out with the average variance extracted criteria being $\geq 0.5$ (Sarwono, 2014), shown in Table 4. It also shows the Cross-loading testing conducted by comparing loading on the intended indicator that should be greater than the loading value against other indicators or Loading > Cross Loadings.

Table 4 shows that the entire statement has a loading value $>$ cross loading meaning that the entire statement can be said to be valid because it meets the specified criteria

Furthermore, after testing the validity and all data are said to be valid, a reliability test is carried out with the conditions that must be met, namely Composite Reliability $\geq 0.600$ and Cronbach's Alpha $\geq 0.600$. Table 5 showed the results of the PLS Algorithm - reliability test using the Smart-PLS software. 
Table 4

Average Variance Extracted (AVE) s and Cross-Loadings Test Results

\begin{tabular}{|c|c|c|c|c|c|c|c|c|c|}
\hline & (X1) & $(\mathrm{X} 2)$ & $(\mathbf{Y})$ & $(\mathbf{Z})$ & & (X1) & (X2) & $(\mathbf{Y})$ & $(\mathbf{Z})$ \\
\hline $\mathrm{X} 11$ & 0.787 & 0.408 & 0.580 & 0.430 & Y1 & 0.653 & 0.577 & 0.772 & 0.642 \\
\hline X12 & 0.819 & 0.578 & 0.655 & 0.510 & Y10 & 0.582 & 0.587 & 0.784 & 0.672 \\
\hline X13 & 0.737 & 0.535 & 0.512 & 0.452 & Y2 & 0.531 & 0.553 & 0.766 & 0.602 \\
\hline X14 & 0.745 & 0.395 & 0.574 & 0.473 & Y3 & 0.538 & 0.615 & 0.797 & 0.719 \\
\hline X15 & 0.712 & 0.443 & 0.601 & 0.600 & Y4 & 0.586 & 0.631 & 0.842 & 0.691 \\
\hline X17 & 0.761 & 0.363 & 0.537 & 0.453 & Y5 & 0.615 & 0.472 & 0.776 & 0.624 \\
\hline X21 & 0.534 & 0.714 & 0.569 & 0.554 & Y6 & 0.598 & 0.602 & 0.814 & 0.673 \\
\hline X210 & 0.480 & 0.807 & 0.644 & 0.563 & Y7 & 0.715 & 0.574 & 0.794 & 0.713 \\
\hline X22 & 0.418 & 0.740 & 0.531 & 0.491 & Y8 & 0.553 & 0.566 & 0.740 & 0.619 \\
\hline $\mathrm{X} 23$ & 0.353 & 0.792 & 0.518 & 0.534 & Y9 & 0.616 & 0.678 & 0.782 & 0.705 \\
\hline X24 & 0.444 & 0.701 & 0.581 & 0.510 & Z1 & 0.540 & 0.630 & 0.678 & 0.780 \\
\hline X25 & 0.596 & 0.899 & 0.692 & 0.607 & Z2 & 0.534 & 0.576 & 0.735 & 0.884 \\
\hline X27 & 0.469 & 0.839 & 0.594 & 0.505 & Z3 & 0.559 & 0.521 & 0.709 & 0.811 \\
\hline X28 & 0.479 & 0.847 & 0.616 & 0.600 & Z4 & 0.594 & 0.580 & 0.686 & 0.796 \\
\hline \multirow[t]{3}{*}{ X29 } & 0.491 & 0.803 & 0.572 & 0.553 & Z6 & 0.465 & 0.547 & 0.671 & 0.808 \\
\hline & & & & & Z7 & 0.492 & 0.512 & 0.651 & 0.773 \\
\hline & & & & & Z8 & 0.459 & 0.526 & 0.663 & 0.800 \\
\hline AVE & 0.579 & 0.634 & 0.620 & 0.653 & 0.579 & 0.634 & 0.620 & 0.653 & \\
\hline
\end{tabular}

X1=E-Service Quality; X2=E-Security; Y= Trust; Z=E-Satisfaction

Table 5

PLS Algorithm - Composite Reliability Test Results

\begin{tabular}{lllll}
\hline & Cronbach's Alpha & Composite Reliability & Note & \\
\hline (X1) E-Service Quality & 0.854 & 0.892 & Valid & \\
(X2) E-Security & 0.927 & 0.939 & Valid \\
(Y) Trust & 0.932 & 0.942 & Valid \\
(Z) E-Satisfaction & 0.911 & 0.929 & Valid & \\
\hline
\end{tabular}

Table 6

Hypothesis Testing Results

\begin{tabular}{|c|c|c|c|}
\hline Hypotheses & Original Sample $(\mathrm{O})$ & T-statistics & $p$ \\
\hline (X1) E-Service Quality $\rightarrow(\mathrm{Y})$ Trust & 0.499 & 5.784 & 0.000 \\
\hline (X1) E-Service Quality $\rightarrow$ (Z) E-Satisfaction & -0.030 & 0.465 & 0.642 \\
\hline$(\mathrm{X} 2)$ E-Security $\rightarrow(\mathrm{Y})$ Trust & 0.448 & 5.353 & 0.000 \\
\hline$(X 2)$ E-Security $\rightarrow(Z)$ E-Satisfaction & 0.198 & 2.777 & 0.006 \\
\hline (Y) Trust & 0.723 & 16.665 & 0.000 \\
\hline (Z) E-Satisfaction & 0.745 & 15.062 & 0.000 \\
\hline
\end{tabular}

Table 6 shows the $p$-value $0.000<0.05$ which has the meaning of H1 is accepted and there is an effect between e-service quality on trust. T-statistical value is $5.784>$ t-table of 1.96. It has the meaning that the effect between e-service quality variables on trust is significant. Furthermore, the original sample value of 0.499 which showed an effect of a positive direction. However, in testing the effect of e-service quality on e-satisfaction, the results showed $p$-value $0.642>0.05$ which means there is no effect between e-service quality and e-satisfaction. Thus, the hypotheses are rejected. Similarly, the T-statistical value of $0.456<$ t-table 1.96 means that there is no effect between the e-service quality on the trust.

In terms of the effect of e-security on trust, the results showed $p$-value of $0.00<0.05$ which has the meaning that there is an effect between e-security and trust. The result of T-statistical value is $5.353>$ t-table of 1.96 . It has the meaning that the effect of e-security on trust variables is significant. Furthermore, the original sample value of 0.448 showed an effect of positive direction. Thus, H3 is accepted.

In testing hypothesis 4 about the effect of e-security on e-satisfaction, the results showed $p$-value of $0.006<0.05$, which means that there is an effect between e-security on e-satisfaction. Similarly, the t-statistic value of $2.777>$ t-table of 1.96 means that the effect of the e-security on e-satisfaction is significant. Furthermore, the original sample value is 0.198 which shows an effect of positive direction. Thus, $\mathrm{H} 4$ is accepted.

Moreover, in examining the simultaneous effect of e-service quality and e-security on trust, the results showed $p$-value of $0.000<0.05$ which has the meaning there are simultaneous effects between e-service and e-security on trust. This is enforced by the result of T-statistical value of $16.665>t$-table of 1.96 means that the effects between E-Service variables and E-Security simultaneous effects on trust is significant. Furthermore, the original sample value was 0.723 which showed an effect of a positive direction. Thus, H5 is accepted

Lastly, the results about the effect of trust on e-satisfaction revealed the $p$-value of $0.000<0.05$. This, H6 is accepted. It empirically proved a positive effect of trust on e-satisfaction. The value of T-statistic $15.062>\mathrm{t}$-table of 1.96 means that the 
effect between the trust variable on e-satisfaction is significant. Furthermore, the original sample value is 0.745 which shows an effect of positive direction.

\section{Discussion}

The statistical output showed that there is a significant effect between e-service quality on trust with a value of 0.499 . This is in line with research conducted by Rita et al. (2019) that there is a significant effect between e-service quality on trust. These results indicate that e-commerce application users in the Facebook feel that services for online shopping both through the Tokopedia application and the website that are provided can increase consumer trust, one of which is that the e-commerce provides easy access, provides clear information on the products offered, provides various kinds of offers (Gaffar et al., 2020). Regarding the results that there is no effect between e-service quality on e-satisfaction, this result was in contrast to the results of research conducted by Rita et al. (2019). In the virtual market, a good e-service quality is the main thing that every online shop must have, where if e-service quality is good it means that it can function properly without any errors. It can have a big effect on the level of customer satisfaction or e-satisfaction. The results showed that users of e-commerce apps in Facebook felt that the service to online shopping either through apps or the website provided was unsatisfactory because the site was not functioning properly, accuracy of poor service promise, slow response to complaints (Lwoga \& Lwoga, 2017).

The results showed that there is a significant effect between e-security on trust with a value of 0.448 . It shows that the ecommerce provides security guarantees and data confidentiality. Nilashi et al. (2015) stated that building customer trust is a complex process that involves business and technology practices. Gaining customer trust in mobile commerce is a particular daunting task and plays a major influence on a customer's decision-making behavior. A trusted website can provide mobile commerce with powerful competitive advantages. Security is one of the factors toward consumer trust (Marriott \& Williams, 2018). Regarding a significant effect between e-security on e-satisfaction with a value of 0.198 , it provides the importance of e-security as a critical thing that needs to be considered by online shops. The e-security provided by the online shop is good and will affect the level of customer satisfaction or e-satisfaction. The output also showed that service quality and e-security have simultaneous affects on trust with a value of 0.723 . This is in line with the research conducted by Abid \& Purbawati (2020) that e-security and e-service quality together have a positive and significant influence on e-satisfaction. Finally, regarding significant effect trust on e-satisfaction with a value of 0.745 , this is in line with research conducted by Laely (2016). This means that the existence of good e-service quality and e-security will have a significant effect on e-satisfaction. Security on the site is one of the important things that online website companies must think about, the presence of e-commerce with all its advantages, such as making transactions easier, also creates various problems such as fraud. This is very influential on customer satisfaction. Low customer satisfaction can be minimized by continuously improving e-service quality and security systems (e-security) on the site so that consumers get high satisfaction.

\section{Conclusion}

The research results have revealed that there is a significant effect between e-service quality on trust, while e-service quality has no significant effect on e-satisfaction. Meanwhile, e-security has a significant effect on trust and e-satisfaction. There is a simultaneous effect of e-service quality and e-security on e-satisfaction, but the value is lower than the effect of trust on esatisfaction. In this study, service quality does not affect online customer satisfaction, therefore it is necessary to make a new study to develop a variable quality of online shopping services considering the many channels used for shopping. maybe need to be more specific considering the characters in each country are very different. Further research also needed to determine the factors that can affect trust because in e-commerce where the buyer and seller do not meet directly, the trust between the two is a determining factor for post-purchase.

\section{References}

Abid, M. M. F., \& Purbawati, D. (2020). The Effect of E-Security and E-Service Quality on E-Repurchase Intention with ESatisfaction as an Intervening Variable for Lazada E-Commerce Consumers in the Undip Fisip. Journal of Business Administration Science, 10(1), 93-100.

Bi, Y., \& Kim, I. (2020). Older Travelers' E-Loyalty: The Roles of Service Convenience and Social Presence in Travel Websites. Sustainability, 12(1), 410.

Bulut, Z. A. (2015). Determinants of repurchase intention in online shopping: A Turkish consumer's perspective. International Journal of Business and Social Science, 6(10), 55-63.

Chang, M. K., Cheung, W., \& Tang, M. (2013). Building trust online: Interactions among trust building mechanisms. Information \& Management, 50(7), 439-445.

Chauke, X. D., \& Dhurup, M. (2017). A generation X cohort analysis of E-shoppers: Satisfaction, loyalty and repurchase intentions in a developing country. Journal of Social Sciences, 52(1-3), 145-154.

Chong, A. Y. L., Darmawan, N., Ooi, K. B., \& Lin, B. (2010). Adoption of 3G services among Malaysian consumers: an empirical analysis. International Journal of Mobile Communications, 8(2), 129-149.

Devita, V.D. (2020). Report: Peta Persaingan E-Commerce Q3 2020. Retrieved from https://iprice.co.id/trend/insights/report-peta-persaingan-e-commerce-q3-2020/ 
Engel, J. F., Kollat, D. T., \& Blackwell, R. D. (1968). Consumer behavior. New York: Holt, Rinehart \&Winston.

Flavián, C., Guinalíu, M., \& Gurrea, R. (2006). The role played by perceived usability, satisfaction and consumer trust on website loyalty. Information \& Management, 43(1), 1-14.

Gaffar, V., Ridwanudin, O., Trinugraha, B., \& Riswanto, A. (2020). The Influence of Website Navigational Design on Improving Tourism Performance: Empirical Studies on Sport Tourism Providers in Indonesia. Research in World Economy, 10(3), 408-418.

Gounaris, S., Dimitriadis, S., \& Stathakopoulos, V. (2010). An examination of the effects of service quality and satisfaction on customers' behavioral intentions in e-shopping. Journal of services marketing, 24 (2-3), 142-156.

Laely, N. (2016). Analisis pengaruh kepercayaan dan harga terhadap loyalitas pelanggan dimediasi kepuasan pada pt. telkomsel di kota kediri. JMM17: Jurnal Ilmu Ekonomi dan Manajemen, 3(02), 61 - 74.

Liu, T-.S. (2012). Effect of E-Service Quality on Costumer Online Repurchase Intentions. USA: Lynn University

Lwoga, E. T., \& Lwoga, N. B. (2017). User Acceptance of Mobile Payment: The Effects of User-Centric Security, System Characteristics and Gender. The Electronic Journal of Information Systems in Developing Countries, 81(1), 1-24.

Marriott, H. R., \& Williams, M. D. (2018). Exploring consumers perceived risk and trust for mobile shopping: A theoretical framework and empirical study. Journal of Retailing and Consumer Services, 42, 133-146.

Nilashi, M., Ibrahim, O., Mirabi, V. R., Ebrahimi, L., \& Zare, M. (2015). The role of Security, Design and Content factors on customer trust in mobile commerce. Journal of Retailing and Consumer Services, 26, 57-69.

Nuseir, M. T., Arora, N., Al-Masri, M. M., \& Gharaibeh, M. (2010). Evidence of online shopping: A consumer perspective. International Review of Business Research Papers, 6(5), 90-106.

Oliveira, T., Alhinho, M., Rita, P., \& Dhillon, G. (2017). Modelling and testing consumer trust dimensions in e-commerce. Computers in Human Behavior, 71, 153-164.

Oliveira, T., Alhinho, M., Rita, P., \& Dhillon, G. (2017). Modelling and testing consumer trust dimensions in e-commerce. Computers in Human Behavior, 71, 153-164.

Parasuraman, A., Zeithaml, V. A., \& Berry, L. L. (1985). A conceptual model of service quality and its implications for future research. Journal of marketing, 49(4), 41-50.

Raman, A., \& Annamalai, V. (2011). Web services and e-shopping decisions: A study on malaysian e-consumer. Wireless Information Networks \& Business Information System, 2(5), 54-60.

Ranjbarian, B., Fathi, S., \& Rezaei, Z. (2012). Factor Influencing on Customer's E-Satisfaction: A Case Study from Iran. Journal of Contemporary Research Business, 3(9).

Rita, P., Oliveira, T., \& Farisa, A. (2019). The impact of e-service quality and customer satisfaction on customer behavior in online shopping. Heliyon, 5(10), e02690.

Sharma, G., \& Lijuan, W. (2015). The effects of online service quality of e-commerce Websites on user satisfaction. The Electronic Library, 33 (3), 468-485

Srinivasan, S. S., Anderson, R., \& Ponnavolu, K. (2002). Customer loyalty in e-commerce: an exploration of its antecedents and consequences. Journal of retailing, 78(1), 41-50.

Sugiyono. (2017). Metode Penelitian Kuantitatif, Kualitatif, dan R\&D. Bandung: Alfabeta.

Sumarwan, U. (2011). perilaku konsumen: Teori dan penerapannya dalam pemasaran. Jakarta: Ghalia Indonesia.

Tjiptono, F., \& Chandra, G. (2019). Service, Quality \& Customer Satisfaction. Yogyakarta: Andi.

Tran, L. T. T. (2021). Managing the effectiveness of e-commerce platforms in a pandemic. Journal of Retailing and Consumer Services, 58, 102287.

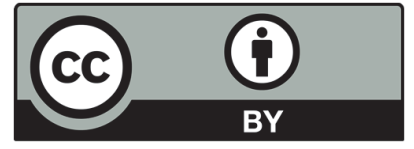

(C) 2021 by the authors; licensee Growing Science, Canada. This is an open access article distributed under the terms and conditions of the Creative Commons Attribution (CC-BY) license (http://creativecommons.org/licenses/by/4.0/). 